\title{
Reorientation of Tax Legal Certainty in Indonesia: An Exploration of Transcendental Law
}

\author{
Henry Dianto Pardamean Sinaga \\ Directorate General of Taxes, The Ministry of Finance of the Republic of Indonesia \\ Jl. Gatot Subroto Kav. 40-42, South Jakarta. \\ Awardee of LPDP at Law Doctoral Program of Universitas Diponegoro \\ E-mail: sinagahenrydp@gmail.com
}

\begin{abstract}
As the constitution has affirmed that Indonesia is a law state based on Belief in the One and only God, so that Indonesia has sovereignty in regulating its tax law transcendentally. However, the domination of the law in books tradition in taxation, as the characteristic of positivism paradigm and modern law, could potentially eliminate the transcendental values, such as religious, ethical, and moral. This tradition has created many disputes between taxpayer and tax authority and at great risk in marginalizing justice and sensible matters in the field of tax law. Given the tax legal certainty that greatly sanctifies the spelling of the text of legislation (whereas every applicable law in Indonesia must contain the meaning of Pancasila) along with the thought that the submission of the tax dispute is the process of seeking justice and legal certainty due to adoption of self-assessment system, and in order to avoid substantial unjustice, not making the contradiction between tax laws and other laws, and avoid stiff administration and slow bureaucracy, it is necessary to reorient the legal certainty of taxes beyond positivism and modernity, or in other words, not only in the lex scripta, lex certa, and lex stricta orientatiton, but also must be oriented towards transcendental law dimension, through a priori and a posteriori synthesis as every applicable law must be built based on grundnorm, Pancasila. As the notion of tax law is for human being and society and in order to generate the conception of tax legal certainty based on the transcendental law, required the primacy of the conscience capacity of the tax apparatus in meaning the tax law based on the ideality and the universal truth of the five principles of Pancasila. It is suggested to regulate the tax legal certainty values explicitly in the renewal framework of tax law, which reflecting solutive actions against the limitations of tax legislation, minimizing tax disputes and creating voluntary compliance.
\end{abstract}

Keywords—a posteriori; a priori; legal certainty, tax; transcendental law

\section{INTRODUCTION}

Constitutional mandate, as ruled in Article 1 paragraph (3) and Article 23A of the Fourth Amendment of the 1945 Indonesian Constitution (UUD 1945), stated that as a state based on law, all taxes collection in Indonesia shall be based on statutes. However, in the course of time, the notion of a law state, with its civil law tradition, has been misinterpreted as the state based on the law's text. This law's style is, regarding in the term of Rahardjo, as a law's way that maintains the status quo and side by side with analytic- positivistic thinking, whose tendency is to accept the law as a final scheme and read the law as spelling rather than reading it meaningfully. This law's style has been worrying because it has become commonplace for the legal community to postulate and redirect it as a reason to maintain legal certainty [1].

The strong influence of the positivism paradigm, as the soul of modernity era, marked by the existence of modern law which is putting forward rational thinking and highly prioritizing procedure that tends to produce formal justice that does not necessarily reflect real justice, because the so-called formal justice itself is not a product that is neutral and free of political bias or other interests [2]. This robust of modernism era, according to Absori, has made transcendental matters in all its aspects, such as religious, ethical, and moral, to be a separate part of modern law [3]. But, this separation between law and transcendental perspective in the modern world can not be justified because the law is for human and society, where Indonesian human and society must always rely on the First Principle of Pancasila, the Preamble of the 1945 Indonesian Constitution, and Article 29 paragraph (1) of the 1945 Indonesian Constitution which is based on Belief in the one and only God. Thus, everyone who deals with taxes must be able to think beyond positivism and modernity, or also known as transcendent thinking [4].

The existence of the mandate of Article 1 paragraph (3) and Article 23A of the 1945 Indonesian Constitution has been realized in the form of tax laws and regulations, but it is still laden with the occurrence of the disputes between the taxpayers (WP) and the tax authorities in Indonesia, namely the Directorate General of Taxes (DGT). The number of taxpayers filing tax objections and tax appeals to the tax court, and the discrepancy between the decision of the District Court (Pengadilan Negeri-PN), the High Court (Pengadilan Tinggi-PT), and the Supreme Court (Mahkamah Agung-MA) in a tax crime are some facts proving that legal certainty has been misinterpreted be 
merely a certainty of the statutes or the certainty of written rules.

Tax disputes in Indonesia are still a lot going on. Based on the DGT's 2015 Annual Report, the settlement of tax disputes processed by the DGT from 2012 to 2015 were about $1.938 .889,-$, of 1.886 .317 , -, of $54, .87,-$, and of 112.038 , - tax disputes respectively. These disputes included correction, objection, tax deduction, reduction or elimination of administrative sanctions, deduction or cancelation of tax assessment letters (SKP) and tax bill (STP), and cancellation of tax audit/SKP result. Indeed, the occurrence of tax disputes during this time not only can be interpreted as a result of the application of the law as a final scheme and as a spelling of the Law, but also can be interpreted as a means of seeking tax justice and or legal certainty for Taxpayers, as arising of the characteristics and patterns of tax collection system which adopted the self assessment system in Indonesia. So that, the calculation of real tax payment for state revenue will be certain if it has obtained a decision of a court that has final and binding legal force (inkracht) and/or has passed the issuance of SKP pursuant to Article 13 paragraph (4) of the of Law Number 6 of 1983 regarding General Requirement and Tax Procedure as Lastly Amended by Law Number 16 of 2009 (KUP Law) and/or has passed the tax criminal prosecution pursuant to Article 40 KUP Law. The understanding of the term self-assessment, in the context of the tax collection system in Indonesia, is all Taxpayers who have fulfilled subjective and objective requirements: (a). Obligatory to register themselves at the Directorate General of Taxes office (Article 2 paragraph (1) in conjunction with Article 4 paragraph (1) KUP Law); (b). Compulsory fill out the tax filing (SPT) correctly, complete, and clear and sign and submit it to the office of the Directorate General of Taxation (Article 3 paragraph (1) KUP Law); (c). Taking own SPT in the place specified by the Director General of Tax (Article 3 paragraph (2) KUP Law); and D). Obligate to pay or deposit their own tax payable by using Tax Payment Deposit (SSP) by not relying on the existence of tax assessment letters (Article 10 paragraph (1) jo. Article12 paragraph (1) KUP Law).

Besides the disputes caused by the pattern and tax collection system in Indonesia, the facts due to the tendency of legal acceptance as a final and merely spelled scheme of the statutes may occur in tax criminal cases. One of the cases due to Supreme Court Decision Number 2628 K/PID.SUS/2016 stated that the defendant DP alias AK was decided on imprisonment and a fine of Rp. 53.88 billion for committing a tax crime. This decision canceled the decision of the South Jakarta District Court Number 819/Pid.Sus/2015/PN.Jkt.Sel. which decided not guilty of the defendant DP alias AK by considering that the defendant did not make a fake ID (Kartu Tanda PendudukKTP) for the purposes of the commissioner of the company. The defendant just followed the order of HP by giving the defendant Rp. 5 million every month.

Other case due to the tendency of legal acceptance as a final scheme and the sole spelling of tax crime is a Supreme Court decision Number 2583 K/PID.SUS/2016 that punished the defendant AT, the director of CV. ANTS, for prison and a fine of Rp. 41,15 billion due to deliberate submission of incorrect or incomplete tax filing (Surat Pemberitahuan-SPT) and/or information, in the form of non-underlying transactions of tax invoices. The defendant, who used invalid tax invoice for VAT tax return from January 2007 to September 2009 with tax loss of Rp.15,13 billion, has been well-intentioned with the installment of Rp.8,27 billion to the State when the preliminary evidence audit was conducted. Regarding with this well-intentioned, some of the expert provide opinions that lighten the defendant. The opinion of Public Budget and Finance Expert stated that the spirit in the public financial regime (including taxes) is an administrative settlement as the state prioritizes for State's revenues, and Criminal Law Expert stated that the administrative limits of settlement due to the process of installment, is a good faith, therefore there is no intention to commit tax violations, and there is a reason for forgiving. The opinion of both experts implies that legal certainty is still limited to the certainty of the statute or regulation. It can be compare for the same case in the issue of a non underlying transactions of tax invoices, which the actions are same but the treatments are different. As the Supreme Court judicial review (Peninjauan Kembali-PK) verdict No. 647/B/PK/PJK/2012 and No. 649/B/PK/PJK/2012 rejected the application of PT. LSI and verdict of PK MA No. 637 B/PK/PJK/2010 rejected the application of PT. EPJ, regarding to the correction of invalid tax invoices in the Value Added Tax (VAT)-Input. Whereas, against PT. LSI and PT. EPJ were only conducted the process of tax audit that lead to SKP as legal product, not the process of preliminary evidence audit that can lead to the tax crime, as it has been done against the defendant AT. Moreover, the imposition of accrued taxes through the tax audit process was disputed by PT. LSI and PT. EPJ by filing an objection procedure, then appeal to the tax court, and finally filing the PK to the Supreme Court.

Considering the domination of the law in books tradition in tax legal certainty, however there are many disputes between the taxpayers and the tax authorities by the reasoning of seeking justice and legal certainty as a result of the adoption of self-assessment system, so that there are two main research problems in this article. First, why the tax legal certainty in Indonesia should be reoriented? Two, how to reorient the tax legal certainty in the transcendental law?

\section{RESULT AND DISCUSSION}

\section{A. Orientation and Reorientation of Tax Legal Certainty in Indonesia}

The civil law style, which is identified by its positivism and modernity, has strongly emphasized the role of written laws to ensure legal certainty. Thus, according to Rahardjo, it has led to being the ideology (of legal certainty) that can cause people to become fixated on text regulation readings, so it will be at great risk in marginalizing justice and sensible matters in the field of tax law [5].

It is acknowledged that the positivism paradigm is still needed, especially in the field of taxation, because of 
the need to formulate the rules explicitly in order to ensure the existence of (tax) legal certainty as mandated in Article 1 paragraph (3) and Article 23A of the 1945 Indonesian Constitution. Moreover, there is the assumption of the positivism paradigm stated that the only accepted law as the rule gets its positive form from the authorized institution [6]. These thoughts that are identical with logical-empirical, objective, reductionist, deterministic and value-free thinking identifies that legal positivism is considered as the more useful law in Indonesia. Then, about the appearance of modernity is in line with the state's duty, as an organization of sovereign power in a territory, in protecting and maintaining the interests of its people. So that, the modernity in the form of modern law must have the characteristics of modern law, as Max Weber proposed its 5 (five) characteristics, namely: (1) "normative" legal rules, which are common and more or less abstrac ; (2) "positive" law in the form of conscious decisions; (3) reinforced by coercive "power" of the state in the form of sanctions in case of violation; (4) systematic, as meaned as a system of normative thought which is logically consistent and rational, and all practical problems of a legal nature can be solved by law; and (5) secular, meaning that its substance is completely separate from its religious, ethical, moral considerations and its procedures seeks to achieve rational and humane intentions [7].

The emphasizes of positivism and modernity to ensure legal certainty have influenced tax laws as its existences in some "legal certainty" words of tax statute, such in elucidation of Article 2 paragraph (4a) of the KUP Law confirms the legal certainty to the Taxpayer and the Government in the case of issuance of Taxpayer Identification Number (Nomor Pokok Wajib Pajak-NPWP), Article 17B paragraph (2) of the KUP Law confirms the legal certainty of tax audit period for taxpayer refund or taxpayer overpayment, Article 22 paragraph (1) of the KUP Law asserts the legal certainty of expiration of tax debt collection, and Article 40 of the KUP Law confirms the legal certainty for Taxpayers, Public Prosecutors, and Judges in expiration of tax criminal offenses. But these articles only limit to the words, without adequate explanation. Even, the existing definition only in tax amnesty context as elucidated in Article 2 paragraph (1) of the Law Number 11 of 2016 regarding Tax Amnesty (Tax Amnesty Law) which states "the principle of legal certainty in the implementation of tax amnesty is the implementation of tax ability that must be able to realize an order in society through legal certainty guarantee. Indeed, although the tax laws and regulations have not been directly regulated understanding of legal certainty, there is an explicit definition of legal certainty in other administrative law, such in elucidation of Article 3 of Law Number 28 of 1999 regarding The Implementation of Clean and Free State of Corruption, Collusion and Nepotism, as a principle in a rule of law state that prioritizes the basis of legislation, appropriateness, and justice in any public policy. However, the definition is ambiguous (legal certainty for whom? Is it for dutiful taxpayers or for disobedience taxpayers?) and does not touch upon the substance of tax legal certainty.
Due to the ambiguous understanding of legal certainty in certain legislation and the lack of deep understanding related to tax legal certainty (which tends to be understood as a statute certainty), it is necessary to deeply explore the real meaning of legal certainty by understanding the thoughts of legal thinkers. Radbruch asserted that a legislation is enforced through the existence of state power which contains obligations and legal validity. It must be realized that legal certainty is not the only factor in the implementation of the law or as the only value, but the validity of the law must be in line with the other two values: public benefits and justice [8]. Furthermore, Radbruch's notion, of lawlessness which not depends solely on legal certainty, is reinforced by Rahardo's assertion that statutes are not the only factor that leads to legal certainty, there are also tradition and behavior factors. If legal certainty is only attributed in absolute terms of the legislation, what actually appears is "statute certainty", not yet legal certainty. It is still raises doubts, because in the world of legislation, a statute may conflict with other statutes [9]. Thus, the limitations of legal certainty on the formation of laws and regulations must be re-attached to all actions of law enforcement by always running the law due to guidance of the capacity of conscience which contains honesty, empathy, and dedication in enforcing the law [10].

Moreover, about legal certainty, Utrecht argued that legal certainty includes certainty due to the law and certainty in or from the law. Certainty due the law is achieved if legal duty ensures the legal certainty of societal relationships in which the two other law's tasks must be summarized, namely the guarantee justice of the and the public benefit of the law. The certainty in (or from) the law is achieved if the law is as much as on the law, such as statute, rule, and/or regulation, will not be contradictory in its provisions, or in other meaning, an act is based on a logical system, that is according to logic and certainty, the act is based on legal reality, and there are no terms in statute that can be differently interpreted [11]. Later, Asshiddiqie opined that in every rule of law state, all acts of the government shall be based on legitimate and written laws that must exist and apply in advance or precede of the actions or the deeds of the undertaken administrations. But it is admitted that the existence of a normative principle, which requires that any administrative action must be based on 'rules and procedures', may lead to stiff administration and slow bureaucracy, so it is needful to balance the secured space for state administrative officials in carrying out its duties. The balancer is known as the principle of discretion, which allows state officials or state administrations to develop and establish their own 'beleidregels' or 'policy rules' independently and autonomously in the course of carrying out the charged duties by legitimate regulations [12].

In order to know and understand the legal certainty in the tax context, it is necessary to understand the concept of grundnorm [13] in the hierarchical Stufenbeautheorie of Hans Kelsen. or Gardner's terms as the basic norm, which stated that the legal system is a hierarchy of laws [14] which within this legal hierarchy, a legal provision derived from higher provisions, and the 
highest provision is grundnorm which its nature is hypothetical [15]. Subsequently, Hans Nawiasky developed the Stufenbeautheorie of Hans Kelsen in the form of hierarchical regulation groups [16]: (1) The grundnorm, which is the ultimate basis for further regulations. (2) The basic rules of the state or Constitution, which determine the norms that guarantee the sustainability of state and maintenance of the rights of the society. This rule is general and contains no sanctions, excluding statute. (3) The formal law, in which sanctions have been imposed and enacted in order to regulate the further matters contained in the Constitution. And (4). The implementation of autonomous rules and regulations. The deep understanding of the conception of grundnorm confirms that tax legal certainty, as well as tax law enforcement should not only be formallegistic and or just lead to pro justitia process, but it should be possible to ensure a fair and beneficial legal certainty by legal settlement of outside the court through processes of the non - pro justitia concept [17] or reflecting legal sociology concept [18]. It means, tax legal certainty should not only be interpreted as a regulatory system that is lex scripta, lex certa, and lex stricta, due to the nature of tax as social phenomenon and the credo of law stating law is for human being then the tax law should make a sustainable adjustment in achieving its objectives based on the fairness and the public benefit reasoning for real goodness of society [19].

The real goodness of tax society, the society including the taxpayers and the DGT apparatuses, can be achieved through the view that law is also a reality (not only as a statute) which its functions is to renew and or to build its society by not only based on a set of tax laws and regulations but should also include other factors such as economics /moral /ethical factors, and/or other factors whose values and ideas are universally lived within its society. Thus, the tax legal certainty of the DGT apparatuses is inherent in all of its actions in implementing (tax) law with the capacity of conscience, which contains the moral obligation to practice the First Principle of Pancasila, where therein honesty, empathy, and dedication in applying the law [20]. Given the capacity of conscience in the DGT apparatuses, there is an integrity to perform the duties beyond the positivism paradigm and modern law as its continuity to link with each higher level of legal decisions, until to the highest level so-called grundnorm, which in the Indonesian context is reflected on transcendental thinking that is Belief in the One and only God.

\section{B. Reorientation of the Indonesian Tax Legal Certainty in Exploration of Transcendental Law}

The existence of reorientation of tax legal certainty that meets with the solely formal justice, which does not ask for fair or unfair as long as refer to lex scripta, lex certa, and lex stricta system, become shifting toward substance and formal legal certainty in ensuring the existence of fairness and public benefit that wholly attributable to the conception of grundnorm, provided that the DGT apparatuses as the tax law enforcer act with their overall capacity of conscience. It denotes that the tax legal certainty has reached its exploration on transcendental dimension.

The attachment of transcendental dimension on law in reorienting the tax legal certainty must be interpreted as a moral obligation for DGT apparatuses to accentuate substantive justice for human and humanity whose nature always want to interpret every written law which therein the realm of fact in order not to be out of the universal truth of law as born from nature ideal. This is absolutely important for reducing the stiffness of tax legal certainty ideology in the form of a statutory text, which can ignore the limits of ratios and values in the absolute thoughts of truth which are believed from the ideal world. this is in line with the Radbruch's affirmation for the obligation and validity of the law that not absolutely based on merely legal certainty, but must be in line with other values of law, namely public benefit and justice, as completely quoted below: [21]

\begin{abstract}
"Obligation and legal validity must be based, rather, on a value inherent in the statute. To be sure, one values come with every positive-law statute without reference to its content: Any statutes is always better than no statute at all, since it at least creates legal certainty. But legal certainty is not the only value that law must effectuate, nor is it the decisive value. Alongside legal certainty, there are two other values: purposiveness and justice."
\end{abstract}

Discussing about transcendental law cannot be separated from transcendental notion which derived from the Latin "transcendere" which means climbing at / up, as Absori comprehended it as a wider range which is crossborder (can be cross-religious, ethical, and morality that can be dialogued and discussed) in the form of nature physical and metaphysical [22]. Transcendental thinking also cannot be separated from the thought of Immanuel Kant who stated that a study called "transcendental" when focusing on the pure conditions of the subject of knowledge. In relation to this transcendental thought, Kant actually wanted to create a synthesis between empiricism, which emphasizes $a$ posteriori knowledge, with rationalism that emphasizes $a$ priori knowledge [23]. The transcendental idealism, which Kant proposed as the synthesis of a priori and a posteriori knowledge is based on an idea of a man as the center and subject of creativity that not merely depicts the world, but is capable in changing the world by his/her reason and experience. A priori, which receives a doctrine not by proof but through a belief based on human will, derives from a rationalism based on logic, deductive logic based on values, which must always be restored to a doctrine of nature metaphysical. Whereas a posteriori is a philosophy of empiricism based on an inductive logic that will only be based on concrete evidence, experience, and reality, and do not want to be bound by values [24].

The necessity to combine a priori knowledge and $a$ posteriori knowledge in resulting in a law with the transcendental dimension is based on the difficulty of relying on only one knowledge. As Casey and Ricoeur stated that if wanted to keep the 5 (five) ideas of a priori, namely a priori as a formal, a priori as a perceived, a priori as constitutive, and a priori as known a priori, so do not 
blame the empiricism, but appreciates it as the special aspects of the experience. Because empiricism does not exempt a priori idea, merely debating the conception proposed by empiricism and by certain types of idealism [25]. Furthermore, Benfield also asserted that any sufficient knowledge analysis should include $a$ priori and a posteriori knowledge where some experts have resisted solely $a$ posteriori knowledge, as quoted as follows [26] "The assumption they all tend to operate whereas a priori knowledge can be analyzed in some reasonably standard manner such as the justified true belief approach".

In getting the deep understanding of a priori and a posteriori knowledge in law's context, it is important to exemplify with the argumentation of Jegalus who stated that a priori problems can arise in terms of their pure nature and in the reflection of the prejudices of an era. The problem of the pure a priori is associated with empirical human beings due to many empirical features which leads to the unclear criterion for empirical characteristics, whether they are essential or accidental. While the problem of justifying a priori understandings of an age is evident from several facts that have occurred, such as the enactment of the natural law of the Middle Ages which saw the Church always ahead and above the State, the justification of Hobbes's absolute monarchy, and the justification of constitutional monarchy by Locke and Montesque [27]. In addition, Bruggink argued that the law remains weak when it rests only on a priori or only on a posteriori, whose representation is in combination with the following two groups of theories. The first group deals with theories built on empirical materials, but there are problems that question whether the rules of law are sufficient to be studied in an empirical way. The second group deals with the placement of normative or material effectiveness in important positions, but there are problems that question that people can still empirically determine a certain rule to be more obeyed by society when compared with the difficulty of confronting the acceptance based on the values embodied in the rule of law [28].

The description relates to combinations of $a$ priori and a posteriori in the law, indicating the time for contemporary legal certainty development to turn to transcendental law, which juridical philosophy is sufficient to rediscover grundnorm. Philosophically, transcendentalism as the synthesis between empiricism and rationalism should be preceded by the investigation of knowledge through the limits of its ratio, and then to investigate the facts. More legally, as an attempt to achieve its exploration in the form of transcendental law through the synthesis of a priori knowledge with a posteriori knowledge, transcendentalism must first be through metayuridic imperatives which are the content of grundnorm. As Hans Kelsen asserted that das sein and das sollen are closely related to the question of the will to a man as the initial basis for doing, not doing or should do. Then in doing what should be, must be based on the human will which is very subjective in nature. Thus, in growing the necessity that applies to many people, needed the similarity of the will to each person, indicating the similarity of subjectivity to each person. Subsequently, the subjectivity of each person is common sense and form the collective consciousness as a necessity, which in this case is grundnorm [29]. This Grundnorm, in the context of Indonesian, is Pancasila, which should always be the basis for the limitation of a statute and/or written rules that could provide the tax legal certainty. And juridically, it can be asserted that the legal source of taxation that can be used by the competent authority in carrying out legal certainty, at least holding on to the type and hierarchy of legislation, as closely related to the ideas put forward by Hans Kelsen and Hans Nawiasky, applicable in Indonesia which includes the 1945 Indonesian Constitution, the Decree of the People's Consultative Assembly, the Laws/the Governmental Regulations in Lieu of Laws, the Governmental Regulations, the Presidential Regulations, the Provincial Regulations, and the Regency/City Regulations, and the Type of Legislation referred to Article 7 paragraph (1) Law Number 12 of 2011 regarding Establishment of Legislation which is acknowledged its existence and has legal binding as long as it is commanded by a higher Legislation.

Given common sense and collective consciousness as a necessity, it can be said that grundnorm of Pancasila as the sources of legal certainty. This legal certainty based on Pancasila is what must always be the reflection of the DGT apparatuses in ensuring the implementation of tax legal certainty, with the imperative on the understanding of Belief in the One and only God. Thus, the DGT apparatuses will be able to analyze the potential issue of tax disputes and tax law enforcement for not only from the sole law science perspective which have limitations due to the pure attachment for the analysis of doctrine law concept. So that, the DGT apparatuses should perform tax collection by not merely spell laws and regulations but must also broadening it through interpreting the statutes and regulations. Broadly highlight, a transcendental-based meaning can be attributed to the Pancasila which affirms that the public, the Taxpayer and the DGT apparatuses, share the universal truth values by binding the tax rights and obligations before God, in accordance with their respective religions and beliefs. With Belief in the One and only God, the obstacles and weaknesses of legal certainty must be solved due to its utility becomes the ethical foundation of the Indonesian life, which animates, underlies, and guides the realization of a just and civilized humanity, the Indonesian unity, the wisdom in the deliberations / representatives, and the social justice for all Indonesian people [30].

\section{CONCLUSION}

Based on the introduction and discussion above obtained two conclusions. Firstly, the tax legal certainty in Indonesia should be reoriented from sole lex scripta, lex certa, and lex stricta in the field of taxation to the certainty of legal values (the general benefit of the tax as much as possible for the the welfare of Indonesian people, the certainty of taxation legislation, and the fairness between substantial justice and formal justice) which can always be attributed to the Pancasila (in the case of the limitations and/or the differences in the interpretation of written tax laws) by 
holding to the credo that the law is for human being, so that the function of enforcing the tax legal certainty should be based on the overall capacity of the conscience of the tax apparatuses. The reorientation of tax legal certainty is important due to the orientation of the tax legal certainty so far has always been related with greatly sanctifies the spelling of the text of legislation (whereas every applicable law in Indonesia must contain the meaning of Pancasila) along with the thought that the submission of the tax dispute is the process of seeking justice and legal certainty due to adoption of self-assessment system, and in order to avoid substantial unjustice, not making the contradiction between tax laws and other laws, and avoid stiff administration and slow bureaucracy, so it is necessary to reorient the legal certainty of taxes beyond positivism and modernity.

Secondly, the reorientation of tax legal certainty in Indonesia in the dimension of transcendental law should be interpreted and meaned as a moral duty of the DGT apparatuses to accentuate the legal values (the legal certainty tha always along with public benefit and fairness) in meaning or interpreting every written law (which is in the realm of fact) of the laws born of the ideal realm, because the law exists for humans and humanity. It means, this moral duty is not only in the context of lex scripta, lex certa, and lex stricta orientation, but also must be oriented towards transcendental law dimension, through a priori and a posteriori synthesis as every applicable law must be built based on grundnorm, Pancasila. As the notion of tax law is for human being and society and in order to generate the conception of tax legal certainty based on the transcendental law, required the primacy of the conscience capacity of the tax apparatuses in meaning the tax law based on the ideality and the universal truth of the five principles of Pancasila.

It is suggested to regulate the tax legal certainty values explicitly in the renewal framework of tax law, which reflecting solutive actions against the limitations of tax legislation, minimizing tax disputes and creating voluntary compliance.

\section{REFERENCES}

[1] S. Rahardjo, Hukum Progresif: Sebuah Sintesa Hukum Indonesia, Yogyakarta: Genta Publishing, 2009, pp. 90, 91.

[2] F. A. Samekto, Studi Hukum Kritis: Kritik Terhadap Hukum Moden, Bandung: PT. Citra Aditya Bakti, 2005, p. 6.

[3] Absori, "Epistemologi dan Legalisasi Hukum Transendental," dalam Hukum Transendental: Pengembangan dan Penegakan Hukum di Indonesia, Yogyakarta, Genta Publishing, 2018, p. 31.

[4] Suteki, "Hukum Progresif: Hukum Berdimensi Transendental dalam Konteks Keindonesiaan," dalam Hukum Transendental: Pengembangan dan Penegakan Hukum di Indonesia, Yogyakarta, Genta Publishing, 2018, p. 11.
[5] S. Rahardjo, Biarkan Hukum Mengalir: Catatan Kritis tentang Pergulatan Manusia dan Hukum, Jakarta: Penerbit Buku Kompas, 2008, p. 85.

[6] T. Huijbers, Filsafat Hukum dalam Lintasan Sejarah, Yogyakarta: Penerbit Kanisius, 1982, pp. 128, 129.

[7] K. Dimyati, Teorisasi Hukum: Studi Tentang Perkembangan Pemikiran Hukum di Indonesia 1945-1990, Surakarta: Muhammadiyah University Press, 2004, pp. 87, 88.

[8] G. Radbruch, "Statutory Lawlesness and Supra-Statutory Law (1946)," Oxford Journal of Legal Studies, vol. 26, no. 1, p. 6, 2006.

[9] S. Rahardjo, 2008, Op.cit.,, pp. 78, 79, and 84.

[10] S. Rahardjo, 2009, Op.cit., , p. 4.

[11] E. Utrecht, Pengantar Dalam Hukum Indonesia, Jakarta: Penerbit Sinar Harapan, 1989, pp. 13, 62.

[12] J. Asshiddiqie. [Online]. Available: www.jimly.com/makalah/.../57/Konsep_Negara_Hukum_Indonesi a.pdf. [accessed 44 2014].

[13] H. D. P. Sinaga, "The Criminal Liability of Corporate Taxpayer in the Perspective of Tax Law Reform in Indonesia," Mimbar Hukum, vol. 29, no. 3, p. 546, 2017.

[14] B. A. Gardner, Black's Law Dictionary, USA: Thomson West, 2004.

[15] L. Rasjidi and I.T. Rasjidi, Pengantar Filsafat Hukum, Bandung: Penerbit Mandar Maju, 2010, p. 60.

[16] A. G. Anshori, Filsafat Hukum Sejarah, Aliran dan Pemaknaan, Yogyakarta: Gajah Mada University Press, 2006, p. 42.

[17] R. Prasetianingsih, "Pengantar Editor," dalam Negara Hukum Yang Berkeadilan: Kumpulan Tulisan Dalam Rangka Purnabakti Prof. Dr. H. Bagir Manan, Bandung, Pusat Studi Kebijakan Negara Fakultas Hukum Universitas Padjajaran, 2011.

[18] S. Rahardjo, Penegakan Hukum Progresif, Jakarta: Penerbit Buku Kompas, 2010, p. 3.

[19] J. Bentham, Teori Perundang-undangan: Prinsip-prinsip Legislasi, Hukum Perdata dan Hukum Pidana, Bandung: Penerbit Nusamedia and Penerbit Nuansa, 2006, p. 25.

[20] S. Rahardjo, 2009, Op.cit.,, p. 4.

[21] G. Radbruch, no. Op.cit.,, p. 6, 2006.

[22] Absori, dalam Op.cit., 2018, p. 23.

[23] F. B. Hardima, Pemikiran-Pemikiran Yang Membentuk Dunia Modern,, Jakarta: Penerbit Erlangga, 2011, p. 114.

[24] F. A. Samekto, Pergeseran Pemikiran Hukum dari Era Yunani Menuju Postmodernisme, Jakarta: Konstitusi Press, 2015, pp. 71 73.

[25] E.S. Casey and P. Ricoeur, The Notion of the A Priori, Illinois: Northwestern University Press, 1966, pp. 55, 56, 72, 85, 104, and 121.

[26] D. W. Benfield, "The A Priori - A Posteriori Distinction," Philosophy and Phenomenological Research, vol. 35, no. 2, p. 151, December 1974.

[27] N. Jegalus, Hukum Kata Kerja: Diskursus Filsafat tentang Hukum Progresif, Jakarta: Penerbit Obor, 2011, pp. 86, 87.

[28] J. H. Bruggink, Refleksi tentang Hukum: Pengertian-Pengertian Dasar Dalam Teori Hukum, Bandung: PT. Citra Aditya Bakti, 2015, pp. 155, 156.

[29] A. Samekto, 2015, Op.cit., , pp. 8, 9.

[30] Sekretariat Jenderal MPR RI, Empat Pilar Kehidupan Berbangsa dan Bernegara, Jakarta: MPR RI, 2012, pp. 42-45. 